\title{
Daha İyi Yaşam Endeksine (DİYE) Göre OECD Ülkelerinde Karşılaştırmalı Analiz
}

\section{Comparative Analysis in OECD Countries by Better Life Index}

\author{
Muhammed Ali KAĞIZMAN* \\ (iD) 0000-0002-1732-7216 \\ Murat ATAN** \\ (iD) 0000-0002-2485-9456

\section{ÖZ}

İnsanlar hayatlarını en iyi yaşam koşullarında sürdürmeyi arzu eder. Bu istek de insanların daha iyi yaşam koşulları sahip oldukları refah düzeyinin yüksekliği ile ilişkilidir. Dünyada ülkelerinin iyi refah koşullarına ulaşması için politikalar geliştirerek, ülkesinin dünya ülkeleri arasındaki refah sıralamalarında üst seviyelere tașıyacak politikaları uygulamak ister. Alan yazın çalışmaları incelendiğinde refah düzeyi sıralaması için uzun yıllar GSYİH göstergeleri kullanılmıștır. Zaman içinde ülkenin refah düzeyini sadece milli gelir belirlemenin yeterli olmadığ 1 bu nedenle yeni bir takım sosyal göstergeler kullanılmaya başlanmıştır. Bu çerçevede OECD 2011 yılı mayıs ayında ilk olarak "Daha iyi Yaşam Endeksi" adında yeni bir refah endeksi önerisinde bulunmuștur. Önerilen endeks on bir ana boyuttan oluşmaktadır. Bu boyutlar refahı açıklayabilecek için ülkedeki yaşam kalitesi ve geliri betimleyen değişkenlerden oluşmaktadır. Bu çalıșmada, OECD'nin yayınladığ Daha İyi Yaşam Endeksi (DIYYE), uzman görüşleri çerçevesinde değerlendirilerek yeniden hesaplanmıştır. DIYE göstergelerinin ana ve alt kriterlerinin ağırlıklandırılmasında SWARA yöntemi kullanılmıştır. DIYE kapsamındaki ülkeler COPRAS yöntemi kullanılarak değerlendirilmiştir. Hem on bir ana kriter için hem tüm kriterler için ayrı ayrı hesaplama yapılmıștır. Çalışmada kullanılan model ile OECD'nin modeli arasındaki ilişkiyi tespit etmek için spearman rho sıra/rank korelasyon analizi yapılmıştır. Analiz sonuçlarında iki model karşılaştırıldığında aralarında güçlü ve aynı yönlü (pozitif) bir ilişki görülmüştür.

Anahtar Sözcükler: Çok kriterli karar verme, SWARA yöntemi, COPRAS yöntemi, OECD, daha iyi yaşam endeksi

\begin{abstract}
People desire to live in the best living conditions. This desire is related to the better living conditions of people and their high level of welfare. All over the world, states want to develop policies for their countries to have high welfare conditions and to implement policies that will bring their country to higher levels in the welfare rankings among the world countries. When the literature studies are examined, GDP indicators have been used for many years to rank the welfare level. In time, new social indicators started to be used with the idea that income alone is not enough to explain we 11-being. In this context, OECD first proposed a new welfare index named "Better Life Index" in May 2011. The proposed index consists of eleven main dimensions. Since these dimensions can explain wellbeing, it consists of variables that include both quality of life and material conditions. In this study, the Better Life Index (BLI) published by the OECD was evaluated and calculated within the framework of expert opinions. The SWARA method was used in weighting the main and sub criteria of BLI indicators. The countries covered by DIYE were evaluated using the COPRAS method. Separate calculations were made for both eleven main criteria and for all criteria. Spearman rank correlation analysis was conducted to determine the relationship between the model used in the study and the model of the OECD. In the analysis results, a very high degree of positive relationship was found between the two models.
\end{abstract}

Keywords: Multi criteria decision making, SWARA method, COPRAS method, OECD, better life index

Önerilen atıf şekli: Kağızman, M. A. ve Atan, M. (2021). Daha İyi Yaşam Endeksine (DIYYE) Göre OECD Ülkelerinde Karşılaştırmalı Analiz. Sosyal Güvenlik Dergisi (Journal of Social Security). 11(2). 379-392.

• Geliş Tarihi/Received: 05/07/2021 • Güncelleme Tarihi/Revised: 25/11/2021 • Kabul Tarihi/Accepted: 27/12/2021

* Arş. Gör., Çukurova Üniversitesi, İktisadi ve İdari Bilimler Fakültesi, Ekonometri Bölümü, alikagizman@gmail.com

** Prof. Dr., Ankara Hacı Bayram Veli Üniversitesi, İktisadi ve İdari Bilimler Fakültesi, Ekonometri Bölümü, murat.atan@hbv.edu.tr 


\section{GİRIŞ}

Tüm insanlar iyi bir hayata taliptir. Fakat "iyi” veya "daha iyi” yaşamın neyi ifade ettiği sürekli tartışılan bir kavram olmuştur. Son dönemlerde refahı ölçmek için uzun bir süredir kullanılan GSYIHH ve benzer klasik makroekonomik istatistiklerin, insanların gelecek ve mevcut yaşam koşullarını tam olarak yansıtamadığına dair endişeler ortaya çıkmış ve GSYİH verilerinin artık insanların hayatında yer alan önemli faktörlere sadece kısmi bir bakış açısı sağladığı genel olarak kabul görülmüştür. Ekonomik sıkıntı dönemleri de dahil birçok dönemde iyi bir işe sahip olmak ya da fiyatı uygun olan konutlara erişim gibi birçok refah kavramını elde etmek önemli bir hale gelmiştir (OECD, 2015: 14).

Refah tam olarak tanımlanması zor bir kavramdır. Çünkü refahı tanımlamak için insanların refaha atfettiği göreceli önemi anlamanın yanı sıra insanların yaşamını birçok yönden incelemelidir. Alan yazında geçerli görülen bir refah tanımının varlığına rağmen, önemli sayıda konu uzmanı veya uzman olmayan kişiler, beslenme, sağlık gibi zorunlu insani ihtiyaçlarının karşılanmasının dışında kişinin hayattaki hedeflerine ulaşmasını, başarıyı hayatında yakalama ve kendini mutlu kılma vb. ihtiyaçlarının da refah tanımı içinde olması gerektiğini düşünmektedirler (OECD, 2015: 18).

OECD (Ekonomik Kalkınma ve İş Birliği Örgütü), uzun yıllardır ülkeleri sosyo- ekonomik değişkenleri ve ülkenin yaşam kalitesi üzerine araştırmalar yapmaktadır. Bu çerçevede OECD son dönemlerde refah ile toplumsal ilerleme ve gelişmenin ölçülmesi için uluslararası çalışmalara öncülük yapmaktadır. Bu konuda kısaca tarihsel sürece bakılırsa ilk olarak 2004 yılında Palermo'da "İstatistik, Bilgi ve Politikalar" konulu ilk Dünya Forumu OECD tarafından düzenlenmiștir. Daha sonrasında OECD ilki 2007 yılında İstanbul'da ve ikincisi 2009'da Busan'da yapılan iki forum ile ülkelerin küresel olarak ilerlemesinin ölçülmesi projesini gerçekleştirmiştir. Bu alanda farklı kurum kuruluşlarda çalışmalar yürütmektedir. Uluslararası karşılaştırmalı istatistik ve politika önermeleri açısından ülkelerin refahını ve refah düzeylerindeki gelişmeyi ölçen OECD bu çerçevede diğer kuruluşlara göre em ön sirada yer bulmaktadır.

OECD yaşam kalitesi ve sosyal göstergeler alanında uzun süredir çalışmakta ve son zamanlarda refah kavramıyla toplumsal ilerlemenin ölçülmesi adına uluslararası yansımalara öncülük etmektedir. OECD, 2011 yılının mayıs ayında yeni bir refah endeksi olan "Daha İyi Yaşam Endeksi”ni önermiş̧ir. OECD bu endeksle sadece ülkelerin servet büyüklüğünü değil aynı zamanda refahı belirleyen değişkenlerini de kullanarak karşılaştırılmasına imkânı sunmuş ve GSYİH' ya refah ölçümü için alternatif bir yöntem olmayı amaçlamıştır (Kasparian ve Rolland, 2012: 1). OECD'nin yayınlamış olduğu endekste kriterler eşit öneme sahip olmasının yanında kriterler kullanıcı tercihine göre ağırlıklandırma imkânı sunmaktadır. Fakat böylesine detaylı bir endekste alt kriterlerin ağırlıklarının değişim olanağı kullanıcılara sunulmamıştır.

Bu çalışmada, OECD’nin yayınlamış olduğu DİYE 2016, 2017 yılı verileri kullanılarak endekse yeni bir ölçüm modeli önerilmiştir. Endeksteki temel ölçüt ve alt ölçütlerin ağırlıklarını belirlemek için on uzmana anket yapılmış ve bu bilgiler SWARA yönteminde kullanılarak ağırlıklar oluşturulmuştur. COPRAS yöntemiyle elde edilen ağırlıklar kullanılarak alternatifler değerlendirilmiştir. Daha sonra kurulan modelde elde edilen sonuç ve bulguları Spearman rho sıra/rank korelasyon kullanılarak daha iyi yaşam endeksi sonuç ve bulguları arasındaki ilişki ölçülmüştür. 


\section{I- SOSYAL POLITTIKA AÇISINDAN DAHA İYI YAŞAM ENDEKSİ (DIYE)'NIN ÖNEMI}

Sosyal politika özellikle halkın ve halkları oluşturan kişilerin daha iyi (sağlıklı) bir yapıya ulaşmasında, refahın sağlanmasında ve tüm bunların sürdürülebilir olmasında ve korunmasında başta gelen bir unsur olmuştur. Bir ülkede toplumsal ve bireysel sosyal politikalar ihmal edilerek tek başına ekonomik büyümenin sağlanması, ekonomik politikaların sosyal etkileri dikkate almadan hayata geçirilme çabası huzur ve barış içinde yaşayan bir topluma ulaşılmasını imkânsız hale getirir. Refah farklı şekilde tanımlanabilir. Genel olarak refah kavramı bireyin veya halkın sağlı, mutluluk ve huzur yani iyilik hali ya da iyi olmanın ekonomik ve sosyal belirleyicisi şeklinde tanımlanabilir. Refah kavramı alan yazında üç farklı şekilde Sosyal refah, Ekonomik refah ve Devlet refahı kullanılmaktadır ve bunlar birbirinden farklı kavramlardır. Sosyal refah genel olarak toplu önlemler veya refahtan yararlanmayı ifade ederken Ekonomik refah piyasa veya formel ekonomi yoluyla güvence altına alınan refah biçimlerini ifade eder. Buna karşın devlet refahı ise, devletin sağladığı sosyal refah tedbirlerini ifade etmektedir.

Sosyal refah, kişilerin, ailelerin ve toplumların daha yüksek düzeyde refahlarının sağlanmasını gerçekleştirmek amacıyla tasarlanan ve geniş bir alanı kapsayan faaliyet ve programlardır. Bu refah seviyesi, sağlık, beslenme, eğitim, iş koşulları, konut, sosyal güvenlik, giyinme, boş zamanı değerlendirme ve kişisel özerklik gibi çeşitli gereksinimlerin karşılanması derecesine bağlıdır. Sosyal refah programları kısaca, belirli koşullara sahip kişilere mal, hizmet ve para yardımı sağlayan kamu programlarıdır. Sosyal politika, sosyal refahla en fazla benzeşen ve bazen onun yerine kullanılabilen bir kavramdır. Ancak, sosyal politika kavramı, sosyal refah kavramından daha geniş anlam içeren bir kavramdır. Sosyal politika sosyal refah kavramının tamamını kapsar ve bu kapsam dışında kalan bazı kavramları da içerir. Bu çerçevede sosyal refah kavramı sosyal politika kavramının bir alt kategorisi olarak düşünülebilir. (http://auzefkitap.istanbul.edu. tr/kitap/sosyal hizmetler_ao/sosyalpolitika.pdf, Erişim tarihi: 12.04.2021).

Sanayi Devrimi’nin ardından I. Dünya Savaşı, Büyük Buhran ve II. Dünya Savaşı gibi süreçleri yaşayan dünya devletleri, savaş sonrasında daha hızlı bir kalkınma ve büyüme sürecine girmişlerdir. Ancak bu süreçte ülkeler ekonomik olarak büyüme ile sosyal gelişim arasında bir ayrım yapmadılar ve ekonomik büyüme ve sosyal gelişmeyi ülkelerin GSYİH üzerinden ölçülmeyi sürdürmüşlerdir. Bu ülkelerde ekonomik büyüme kişi başına düşen GSYİH ile ölçülmüş ve bu ülkelerin ekonomik başarısının ölçülmesinde genel olarak kabul edilen bir gösterge olmuştur. GSYİH, belirli bir yılda bir ülkede üretilmiş olan tüm mal ve hizmetlerin parasal karşılığı olarak tanımlanabilir. Ülkelerin belirli bir yıldaki veya diğer ülkelere göre göreceli ekonomik pozisyonunu belirlemede temel gösterge olarak kullanılır. $\mathrm{Bu}$ tanımlamalardan dolayı pek çok çevre tarafından sosyal refah ile aynı değerlendirilmektedir. Bu yaklaşım, GSYİH'nın ülkenin sosyal refah seviyesini belirleyen bir değiş̧ken olduğuna ilişkin bir teori ile desteklenmemiş olmakla birlikte zamanla alan yazında daha sıklıkla kullanılmıştır (Bergh, 2008, 117- 118 ve 2010, 540).

Stiglitz, vd. (2009) çalışmalarında; bir ülkenin refahını ölçmek ve tanımlamak amacıyla sadece GSYİH gibi tek bir kritere değil, daha fazla ölçüte ihtiyaç vardır. Oluşturulan komisyon yaşam kalitesinin ve refahın ölçümünde sekiz alanın (yaşam koşulları için lazım unsurlar (zenginlik, tüketim ve gelir); sağlık, eğitim ve iş hayatı için gerekli kişisel unsurlar, idare ve politika, sosyal ilişkiler ve bildirişim, itimat ve çevre) ölçülmesi ve kullanılması gerektiğini ileri sürmüş̧ür. 2000'li yıllarda ilerleyen globalleşme nedeniyle çeşitlenen yaşam unsurları ile refahın ölçülmesi ve belirlenmesinde sıklıkla kullanılan gelir yöntemleri eksik 
kalmıştır. Özellikle bu süreçte, genel bir refahın tanımlanmasına ve bu tanımlamaya bağlı olarak ölçülmesinde yeni yaklaşımlara ihtiyaç görülmüştür (Stiglitz, vd., 2009: 14).

2011 yılında OECD, ülkelerin sosyal refah düzeylerini daha kapsayıcı tanımlayan ve ölçümleyen bir endeks "Daha İyi Yaşam Endeksi (DIYYE), Better Life Index" olarak isimlendirilmiştir. DİYE ülkelerin GSYIH gibi gelir unsuru dışında çok farklı unsurları da dikkate alır (Akar, 2014: 2). OECD tarafindan oluşturmuş olan DİYE ülkelerin refah düzeylerini kullanarak çeşitli alanlarda karşılaştırma imkânı sunmaktadır.

\section{II- TARIMSAL OLARAK DAHA İYİ YAŞAM ENDEKSİ (DİYE)}

Fransa Cumhurbaşkanı Nicolas Sarkozy tarafından Şubat 2008'de kurulmuş olan Ekonomik Performans ve Sosyal İlerleme Komisyonunun (EPSPC) amacı, GSYİH'nin ölçümlerle ilgili problemlerini de kapsayacak şekilde ekonomik performans ve sosyal ilerleme endeksi tanımlayıp, daha fazla endeks oluşturabilmek için gerekli ek bilgilere ulaşmak, ölçme araçlarının uygulanabilirliğini saptamak ve istatistiksel verilerin yansız (sapmasız) olarak verilmesini tartışmak şeklinde özetlemiştir (Stiglitz, vd., 2009). Komisyon Eylül 2009'da hedeflerine bağlı kalarak toplumsal refah, mali performans ve sürdürülebilirlik kavramlarının nasıl geliştirilebileceğiyle ilgili olarak içinde otuz tavsiye bulunan bir rapor yayınlamıştır (Kulesza ve Ucieklak - Jez, 2012: 184).

OECD, bu komisyonun yayınlamış olduğu raporun içindeki tavsiyeleri de dikkate alarak, 24 Mayıs 2011 yılında refahı ölçmek ve tanımlamak adına "Daha İyi Yaşam Endeksi" (DIYYE)'yi geliştirmiştir. Mizobuchi (2013)'e göre on bir kriterden oluşan bu endeks otuz dört OECD ülkelerin refahını göstergeler bazında ayrı ayrı karşılaştırma imkânı sağlamaktadır. Kerenyi (2011) çalışmasında DİYE'de refahı belirleyen tüm unsurların belirli bir düzen yerine birleşik endekste benzer ağırlıklarla yan yana sıralanmaktadır.

Daha iyi yaşam endeksinde sunulmuş olan göstergeler uluslararası standartlara göre seçilmiştir. Temel verilerin kalitesi, politikaların uygunluğu, kullanılabilir kavramlar, tekrar derlenme sıklığı ve anket sonuçlarının karşılaştırılabilirliği göz önünde bulundurulmuştur. OECD bünyesinde seçilmesine karar verilen unsurlar, refah kavramını en iyi betimleyen ölçütleri temsil etmektedir (Kağızman, 2020: 10).

Daha iyi yaşam endeksi refahı on bir temel unsur ve bu unsurlara bağlı yirmi dört alt unsurdan oluşmaktadır. DIYYE 2011 yılında OECD'ye üye otuz dört ülkeyi kapsarken 2012 yılında üye olmayan Brezilya ve Rusya da eklenerek otuz altı ülke üzerinden değerlendirilmiştir. Endeks kapsamında değerlendirilen ülkeler Tablo 1'de verilmiştir. Daha iyi yaşam endeksi kapsamında kullanılan ana kriterler ise aşağıda tanımlanmıştır (http://www.oecdbetterlifeindex.org, Erişim Tarihi: 20.12.2020).

Konut: Barınma insan hayatındaki en önemli yaşam standartlarından biridir. Üç alt kriterden oluşmaktadır.

Gelir ve Servet: Gelir insanların istediklerine sahip olmalarına ve temel gereksinimlerini elde etmesine olanak verirken servet bu durumun devamlılığını mümkün kılar. İki alt kriterden oluşmaktadır.

İstihdam: Bireyin yeterli kazanç sağladığı bir işi olması neredeyse tüm insanların ortak bir isteğidir. Dört alt kriterde incelenmiştir.

Sosyal İletişim: Sosyal bağlantıların "iyi olma" durumuna olumlu etkisi olduğu bilinmektedir. Tek alt kriteri vardır. 
Eğitim: İnsanlarla ilişkili en önemli unsurlardan bir tanesi olan eğitim, insanlar için fırsatlar yaratmaktadır. Üç alt kriterden oluşmaktadır.

Çevre: İnsanların yaşam kalitesi fiziksel çevreden oldukça etkilenebilmektedir. İki alt kriteri vardir.

Sivil Katılım: Özellikle demokrasi tarafından yönetilen ülkelerde insanların sesini ifade eden bir kriterdir. İki alt kriteri vardır.

Sağlık: Bireyin sağlıklı olması neredeyse tüm hususlarda yaşamı etkilemektedir. İki alt kriteri vardır. İki alt kriteri vardır.

Yaşam Memnuniyeti: Birey kendi hayatının nasıl gittiği ile ilgili karar verecek yegâne kişidir düşüncesiyle önemli görülmüştür. Tek alt kriter altında incelenmiştir.

Güvenlik: Güvenliğin kısıtlı olduğu ortamlarda insanlar birçok yönden kısıtlanabilmektedir. İki alt kriterden oluşmaktadır.

İş Yaşam Dengesi: Aile ilişkileri, iş, özel hayat gibi birçok unsuru etkilemektedir. İki alt kriterden oluşmaktadır.

Tablo 1. Daha İi Yaşam Endeksinde Değerlendirilen Ülkeler

\begin{tabular}{llllll}
\hline \multicolumn{5}{c}{ OECD'YE ÜYE OLAN ÜLKELER } & \\
\hline Almanya & Çek Cumhuriyeti & İrlanda & Japonya & Meksika & Türkiye \\
\hline Amerika & Danimarka & İspanya & İzlanda & Norveç & Portekiz \\
\hline Avusturalya & Estonya & İsrail & Kanada & Polonya & Yunanistan \\
\hline Avusturya & Fransa & İsveç & Kore & Slovenya & Yeni Zelanda \\
\hline Belçika & Finlandiya & İsviçre & Lüksemburg & Slovak Cumhuriyeti & \\
\hline Birleșik Krallık & Hollanda & İtalya & Macaristan & Şili & \\
\hline \multicolumn{7}{c}{ OECD'YE ÜYE OLMAYAN ÜLKELER } \\
\hline Brezilya & & \multicolumn{2}{c}{ Rusya } & & \\
\hline
\end{tabular}

\section{III- ALAN YAZIN TARAMASI}

Başol, (2018) çalışmasında yapısal eşitlik modellemesi aracılığıyla bir model geliştirme önerisi yapmışlardır. DIYYE kapsamında yaşam memnuniyetini etkileyen dinamikleri keşfetmeyi hedeflemiştir.

Mehdi, (2018) çalışmasında, toplama yöntemlerinden veri odaklı olan stokastik baskınlık verimliliği testlerinden faydalanıp, ülke refahının belirlenmesinde en iyi ve en kötü durum hallerini elde etmeyi amaçlamıştır.

Monika, (2018) çalışmasında ürettiği sıralamalar aracılığıyla, gizli ağırlıklandırma tasarımları ve bu tasarımların DİYE göstergelerinin nihai değerleri için etkilerini ele almıştır.

Hetschko vd., (2016) çalışmalarında yapmış olduğu deney neticesinde, bulguların insanların gerçek tercihlerini yansıtmadığı ifade etmiş ve DIYYE 'ye avantaj sağlayacak politika önerilerinde bulunmuştur.

Akar, (2014) çalışmasında Türkiye'nin DİYE'deki yerini hem göstergeler hem genel sıralama için incelemiş ve değerlendirmiştir. 
Kasparian ve Roland, (2012) çalışmasında DİYE eleştirisel bir bakışla incelemiş ve metodoloji ile ilgili konuları tartışmıştır.

Şenaras ve Çetin, (2016) çalışmasında çok boyutlu ölçekleme analizi kullanarak OECD ülkelerinin benzerliklerini ortaya koymaya çalışmış ve DIYYE kapsamında kriterlerin önem derecesini, birbirlerine yakınlığını ve uzaklığını tespit etmeyi amaçlamıştır.

Yılmaz, (2017) çalışmasında DİYE kriterleri çerçevesinde insan refahı ve milli gelir arasındaki ilişkileri araştırmayı hedeflemiş̧tir.

Decancq, (2015) çalışmasında DİYE’nin nasıl dağıtıma duyarlı bir hale getirilebileceğini tartışmıştır.

Durand, (2013), OECD refah çerçevesini sunmuş ve belirlenen refah göstergelerinin değişebileceğine dikkat çekerek kriterleri tanıtmıştır.

\section{IV- YÖNTEM}

Çok kriterli/amaçlı karar verme yöntemleri, ölçümlenebilen veya ölçülenemeyen birçok izlem ve işlevsel unsuru eş zamanda değerlendirmeye imkân sağlayan, ilaveten karar verirken birden fazla kişiyi de dahil etme olanağı olan analitik yöntemler içermektedir. Karar verirken çok kriterli/amaçlı karar verme yöntemlerinin tercih edilmesi karar verenlere hem verimli kararlar alınmasında hem de alternatiflerin değerlendirilmesi hususunda aracı olmaktadır (Karaduman, 2018: 42).

Çalışmada kriter ve alt kriterlerin ağırlıklıklarını hesaplamak için çok kriterli/amaçlı karar verme yöntemlerinden biri olan SWARA (Stepwise Weight Assessment Ratio Analysis) yöntemi, alternatiflerin değerlendirilmesi aşamasında ise COPRAS (Complex Proportional Assessment) yöntemi kullanılmıştır.

\section{A- SWARA Yöntemi}

2010 yılında geliştirilen SWARA yöntemi günümüze kadar birçok farklı problemin çözümünde uygulanmıştır. Birden fazla uzmanla çalışmaya yeterince uygun ve matematiksel olarak basit bir yapıya sahip olan çok kriterli/amaçlı karar verme yöntemidir (Engür, 2019: 27).

SWARA yönteminin çözüm basamakları aşağıda sıralanmıştır.

1. Adım: Yöntemin birinci adımında önce karar probleminde yer alan karar verici ve kriter topluluğu belirlenir. $\mathrm{Bu}$ problemde $\mathrm{m}$ adet karar verici ve $\mathrm{n}$ adet kriter bulunduğu varsayılmaktadır.

2. Adım: İlk aşamada belirlenen karar vericiler içinden her biri kendi birikimine göre kriterleri önemliden önemsize şeklinde sıralamaya tabi tutar (Gökkısa ve Ayçin, 2019: 306).

3. Adım: Göreli önem düzeylerini belirlemek için bir önceki aşamadaki sıralamada önem sırası ikinci kriterden başlayarak her bir kriter (j) kendinden önce gelen kriterle (j-1) karşılaştırılır. Bu oran "ortalama değerin karşılaştırmalı önemi”" şeklinde isimlendirilir ve $\mathrm{s}_{\mathrm{j}}$ simgesi ile gösterilmektedir (Ayyıldız ve Demirci, 2018: 80).

4. Adım: Her kriter için katsayı değeri $\mathrm{k}_{\mathrm{j}}$ hesaplanır ve $\mathrm{s}_{\mathrm{j}}$ değeri en büyük olan kriterin katsayı değeri " 1 ” değerini almaktadır. Katsayı değeri aşağıda Eşitlik 1 ile tanımlanmıştır (Çakır ve Karabıyık, 2017: 423).

$k_{j}=\left\{\begin{array}{r}1, j=1 \\ s_{j}+1, j>1\end{array}\right.$ 
5. Adım: Tüm kriterler için $q_{i}$ değerleri hesaplanır. Bu değerler çözüm ağırlıklarını gösterir ve bu Eşitlik 2 ile tanımlanmıştır (Gökkısa ve Ayçin, 2019: 307).

$q_{j}=\left\{\begin{array}{r}1, j=1 \\ \frac{q_{j-1}}{k_{j}}, j>1\end{array}\right.$

6. Adım: Son aşamada ise kriterlere ait göreli ağırlıklar hesaplanır. Göreli ağırlık wj simgesi ile gösterilmekte ve Eşitlik 3 ile tanımlanmıştır.

$w_{j}=\frac{q_{j}}{\sum_{k=1}^{n} q_{k}}$

\section{B- COPRAS Yöntemi}

Vilnius Gediminas Teknik Üniversitesi bünyesindeki araştırmacılar Zavadskas ve Kaklauskas tarafından 1996 yılında literatüre önerilen COPRAS yönteminde değerlendirilen alternatifler fayda ve önem düzeyleri dikkate alınarak bir sıralamaya tabi tutulmaktadır (Podvezko, 2011: 137). COPRAS yöntemi değerlendirme aşamasında hem minimum hem maksimum kriter değerleri için kullanılabilmesinin yanında karmaşık kriterler ve birçok alternatif içeren karar verme problemlerinde de kolay bir şekilde uygulanabilmektedir. $\mathrm{Bu}$ özelliklerinden dolayı da birbirinden farklı karar verme probleminde literatürde uygulamaları yapılmıştır (Sarıçalı ve Kundakcı, 2016: 50).

COPRAS yönteminin aşamaları şu şekilde tanımlanabilir;

Modelin başlangıcındaki değerler aşağıdaki gibi gösterilsin.

$A_{i}:$ i. Alternatif

$C_{j}: j$. Değerlendirme kriteri

$w_{j}: j$. de ğgerlendirme kriterlerinin ăğrlı̆

$$
\begin{aligned}
& i=1,2, \ldots, m \\
& j=1,2, \ldots, n \\
& j=1,2, \ldots, n
\end{aligned}
$$

$x_{i j}: j$. değerlendirme kriteri açısından $i$. alternatifin değeri $i=1,2, \ldots, m$ ve $j=1,2, \ldots, n$

1. Adım: İlk aşamada kriter, alternatif ve $x_{\mathrm{ij}}$ değerlerinden meydana gelen karar matrisi oluşturulur. Başlangıç matrisi olarak tanımlanan karar matrisi " $D$ ” ile gösterilmekte ve Eşitlik 4 ile gösterildiği gibidir.

$$
D=X_{i j}=\begin{gathered}
C_{1} \\
A_{1} \\
A_{2} \\
A_{3} \\
\vdots \\
A_{m}
\end{gathered}\left[\begin{array}{ccccc}
x_{11} & x_{12} & x_{33} & \ldots & C_{n} \\
x_{21} & x_{22} & x_{23} & \ldots & x_{2 n} \\
x_{31} & x_{32} & x_{33} & \ldots & x_{3 n} \\
\vdots & \vdots & \vdots & \ddots & \vdots \\
x_{m 1} & x_{m 2} & x_{m 3} & \ldots & x_{m n}
\end{array}\right]
$$


2. Adım: Karar matrisini, normalize edilmiş karar matrisine dönüştürmek için Eşitlik 5 kullanılmaktadır (Şahin ve Öztel, 2017: 78).

$x_{i j}^{*}=\frac{x_{i j}}{\sum_{i=1}^{m} x_{i j}}$

3. Adım: Normalize edilmiş karar matrisinin sütunları ile kriterlerin ağırlık değerlerinin $\left(w_{j}\right)$ çarpılmasıyla, ağırlıklı normalize edilmiş karar matrisi $\left(\mathrm{D}^{1}\right)$ elde edilir ve $d_{i j}$ elemanlarından oluşur. Eşitlik 6 ile hesaplanmaktadır (Uygurtürk ve Soylu 2016: 642).

$D^{l}=\left[d_{i j}\right]=x_{i j}^{*} \times w_{j}$

4. Adım: Ağırlıklı normalize edilmiş matristeki faydalı kriterler toplanarak $S_{i}^{+}$ve faydasız kriterler toplanarak $S_{i}^{-}$elde edilir. Formüller Eşitlik 7 ve 8'de gösterilmiştir.

$S_{i}^{+}=\sum_{j=1}^{k} d i j \quad j=1,2, \ldots, k$ faydall kriterler

$S_{i}^{-}=\sum_{j=k+1}^{n} d i j \quad j=k+1, k+2, \ldots, n$ negatif etkili kriterler

5. Adım: Her alternatifin göreli önem değeri hesaplanır. Qi ile gösterilir ve Eşitlik 9 ile hesaplanır. En yüksek değer $Q_{\max }$ ile gösterilir.

$Q_{i}=S_{i}^{+}+\frac{\sum_{i=1}^{m} S_{i}^{-}}{S_{i}^{-} \times \sum_{i=1}^{m} \frac{1}{S_{i}^{-}}}$

6. Adım: Her bir alternatifin performans indeksi hesaplanır. Performans endeksi $P_{i}$ olarak simgelenir. Eşitlik (10) kullanılarak hesaplanır (Eren, 2016: 55).

$P_{i}=\frac{Q_{i}}{Q_{\max }} \times \% 100$

Performans indeksi değerlerinin sıralanmasıyla alternatiflerin tercih sonuçlarına ulaşılmaktadır.

\section{V- ÇOK KRITERLI/AMAÇLI KARAR VERME MODELLERİ KULLANILARAK OECD ÜLKELERINDE DAHA İYİ ENDEKSİ ÜZERINE BIIR UYGULAMA}

Çalışmanın uygulaması için OECD daha iyi yaşam endeksi 2016 ve 2017 yılı kapsamındaki ülkeler ve göstergeleri veri seti olarak kullanılmıştır. Uzman görüşlerini almak için yapılan anketler neticesinde daha iyi yaşam endeksindeki on bir ana ve yirmi dört alt kriter için gerekli olacak ağırlıkları belirlemek için ilk olarak SWARA yöntemi adımları uygulanmıştır. $\mathrm{Bu}$ adımlar hem tüm ana kriterler için hem endeksin bütünü için hesaplanmış, elde edilen ağırlıkların çarpılması sonucunda ulaşılan son/nihai kriter ağırlıklar değerleri ve bu değerlere göre kriter sıralamaları Tablo 2'de verilmiştir. 
Tablo 2. Nihai Kriter Ă̆ıllıkları ve Kriterlerin Stralaması

\begin{tabular}{|c|c|c|}
\hline Ana Kriterler & Kriter & Nihai Kriter A Ăgrlığı \\
\hline \multirow{3}{*}{ Konut } & C1.1: Temel Donanımlardan Yoksun Konutlar & 0,02182 \\
\hline & C1.2: Konut Harcamaları & 0,01767 \\
\hline & C1.3: Kişi Başına Düşen Oda Sayısı & 0,01824 \\
\hline \multirow{2}{*}{ Gelir ve Servet } & C2.1: Hanehalk1 Y1llık Net Harcanabilir Gelir & 0,05501 \\
\hline & C2.2: Hanehalkı Mali Zenginliği & 0,04695 \\
\hline \multirow{4}{*}{ İstihdam } & C3.1: İşgücü Piyasası Güvensizliği & 0,02123 \\
\hline & C3.2: İstihdam Oranı & 0,02431 \\
\hline & C3.3: Uzun Dönem İşsizlik Oranı & 0,02249 \\
\hline & C3.4: İşe Bağlı Kişisel Kazanç & 0,01886 \\
\hline Sosyal İletişim & C4: Sosyal İletişim & 0,05341 \\
\hline \multirow{3}{*}{ Eğitim } & C5.1: Eğitime Katılım & 0,03581 \\
\hline & C5.2: Öğrenci Becerileri & 0,03136 \\
\hline & C5.3: Eğitimde Geçen Yıl & 0,02229 \\
\hline \multirow{2}{*}{ Çevre } & C6.1: Hava Kirliliği & 0,03190 \\
\hline & C6.2: Su Kalitesi & 0,03355 \\
\hline \multirow{2}{*}{ Sivil Katılım } & C7.1: Geliştirilen Düzenlemeler için Paydaş Katılım & 0,01764 \\
\hline & C7.2: Seçmen Katılımı & 0,02061 \\
\hline \multirow{2}{*}{ Sağlık } & C8.1: Yaşam Beklentisi & 0,11716 \\
\hline & C8.2: Sağlık Beyanı & 0,13365 \\
\hline Yaşam Memnuniyeti & C9: Yaşam Memnuniyeti & 0,10894 \\
\hline \multirow{2}{*}{ Güvenlik } & C10.1: Gece Yürürken Güvende Hissetme & 0,03910 \\
\hline & C10.2: Cinayet Oranı & 0,03690 \\
\hline \multirow{2}{*}{ İş Yaşam Dengesi } & C11.1: Çok Uzun Saat Çalışanlar & 0,03680 \\
\hline & C11.2: Boş Vakit ve Kişisel Bakıma Harcanan Zaman & 0,03429 \\
\hline
\end{tabular}

Tablo 2'ye bakıldığında modelde en yüksek derecede öneme haiz kriterin "sağlık beyanı" kriteri, ikinci kriterin ise yine sağlık ana kriterinin alt kriterlerinden biri olan "yaşam beklentisi" kriteri olduğu görülmektedir. Anketler sonucunda en düşük öneme haiz olan kriter ise "geliştirilen düzenlemeler için paydaş katılım" olarak belirlenmiştir.

SWARA yöntemiyle elde edilen ağırlıkların COPRAS yönteminde kullanılmasıyla alternatiflerin değerlendirilmesi ve sıralaması yapılmıştır. COPRAS yöntemi adımları uygulandığında elde edilen performans indeks değerleri ve alternatiflerin sıralama değerleri Tablo 3'de gösterilmiştir. 
Sosyal Güvenlik Dergisi • Journal of Social Security • 2021/2

Tablo 3. Performans İndeks Değerleri ve Alternatiflerin Stralaması (2016 yılı için)

\begin{tabular}{|c|c|c|c|c|c|}
\hline ALTERNATÍFLER & $\mathbf{P}_{\mathbf{i}}$ & SIRA & & $\mathbf{P}_{\mathbf{i}}$ & SIRA \\
\hline Avustralya & 0,8631 & 10 & Letonya & 0,5824 & 33 \\
\hline Avusturya & 0,8429 & 14 & Lüksemburg & 0,9245 & 6 \\
\hline Belçika & 0,8265 & 15 & Meksika & 0,5371 & 37 \\
\hline Kanada & 0,9335 & 4 & Hollanda & 0,8957 & 8 \\
\hline Şili & 0,5971 & 32 & Yeni Zelanda & 0,8617 & 11 \\
\hline Çek Cumhuriyeti & 0,7276 & 20 & Norveç & 1,0000 & 1 \\
\hline Danimarka & 0,9312 & 5 & Polonya & 0,6646 & 25 \\
\hline Estonya & 0,6456 & 27 & Portekiz & 0,6285 & 29 \\
\hline Finlandiya & 0,8602 & 12 & Slovakya & 0,6607 & 26 \\
\hline Fransa & 0,7908 & 18 & Slovenya & 0,7375 & 19 \\
\hline Almanya & 0,8547 & 13 & İspanya & 0,6875 & 24 \\
\hline Yunanistan & 0,6148 & 31 & İsveç & 0,9777 & 2 \\
\hline Macaristan & 0,6323 & 28 & İsviçre & 0,9548 & 3 \\
\hline İzlanda & 0,8761 & 9 & Türkiye & 0,5604 & 34 \\
\hline İrlanda & 0,8038 & 17 & Birleşik Krallık & 0,8183 & 16 \\
\hline İsrail & 0,7180 & 21 & Amerika & 0,9144 & 7 \\
\hline İtalya & 0,7085 & 22 & Brezilya & 0,5475 & 35 \\
\hline Japonya & 0,6998 & 23 & Rusya & 0,5445 & 36 \\
\hline Kore & 0,6210 & 30 & Güney Afrika & 0,4975 & 38 \\
\hline
\end{tabular}

Model çerçevesinde uygulanan yöntemler neticesinde 2016 yılı genelinde bakıldığında en iyi alternatif "Norveç" ardından "İsveç" ve "İsviçre" gelmektedir. Son sırada OECD üyesi olmayan "Güney Afrika" yer alırken Türkiye 34. sırada yer almaktadır.

Çalışmada 2016 yılında tüm kriterler göz önüne alınarak yapılmış olan model, hem 2017 yılı hem de 11 ana kriter için yapılmıştır. Uygulanılan model sonucu elde edilen sıralamalar ile daha iyi yaşam endeksi sıralaması arasındaki ilişkinin derecesini ve yönünü saptamak için spearman rho sıra/rank korelasyon analizi uygulanmıştır. Bu analizin sonuçları Tablo 4'te gösterilmiştir. 
Tablo 4. Spearman Sira Korelasyon Analiz Sonuçları

\begin{tabular}{lcc}
\hline KRİTERLER & $\begin{array}{c}\text { Model - OECD sira korelasyonu } \\
\text { (2016) }\end{array}$ & $\begin{array}{c}\text { Model - OECD sura korelasyonu } \\
\text { (2017) }\end{array}$ \\
\hline Konut & 0,89 & 0,76 \\
\hline Gelir & 0,99 & 0,90 \\
\hline İstihdam & 0,92 & 0,87 \\
\hline Sosyal İletişìm & 0,98 & 0,95 \\
\hline Eğitim & 0,85 & 0,88 \\
\hline Çevre & 0,98 & 0,96 \\
\hline Sivil Katılım & 0,94 & 0,76 \\
\hline Sağlık & 0,99 & 0,98 \\
\hline Yaşam Memnuniyeti & 0,99 & 0,99 \\
\hline Güvenlik & 0,83 & 0,83 \\
\hline İş Yaşam Dengesi & 0,86 & 0,85 \\
\hline GENEL & $\mathbf{0 , 9 7}$ & $\mathbf{0 , 9 6}$ \\
\hline & &
\end{tabular}

OECD ile çalışmada kullanılan model arasındaki korelasyon katsayılarına bakıldığında; tüm ilişkiler pozitif yönlü, 2017 yılı konut ve sivil katılım kriterleri ile model arasında yüksek derecede ilişki, geri kalan 2016 ve 2017 yılları için tüm sıralamalar arasında çok yüksek derecede ilişki olduğu saptanmıştır.

\section{SONUÇ}

Bu çalışmada SWARA ağırlıklı COPRAS yöntemi kullanılarak 2016 ve 2017 yılları için OECD tarafından hesaplanan daha iyi yaşam endeksinin değerleri yeniden hesaplanmıştır. Bu hesaplamalarda kullanılacak olan ağırlıklandırmanın yapılması için on uzmana yüz yüze anket uygulanmıştır. Çalışmada kullanılan model hem kriterler bazından hem genel endeks bazında hesaplamada kullanılmıştır.

SWARA yönteminin uygulanması sonucunda daha iyi yaşam endeksindeki en önemli kriterler "Sağlık" ana kriterinin alt kriteri olup sırasıyla "Sağlık Beyanı" $(0,1336)$ ve "Yaşam Beklentisi" $(0,1172)$ olarak belirlenmiştir. Önem düzeyi en düşük olan kriter ise "Sivil katılım" ana kriterinin alt kriteri olan "Geliştirilen Düzenlemeler için Paydaş Katılım" $(0,0176)$ olarak belirlenmiştir.

2016 y1lı tüm kriterler toplu bir şekilde göz önünde bulundurulduğunda OECD daha iyi yaşam endeksinde Türkiye 36. sırada yer alırken, çalışmada uygulanan modelde 34 . sırada yer almaktadır. Hem OECD DIYYE endeksinde hem çalışmada önerilen modellerde Norveç 
1. sırada yer almıştır. OECD DIYYE 'de 2.ve 3. sırayı Avustralya ve Danimarka alırken çalışmada önerilen modelde 2. sırada İsveç ve 3. sırada ise İsviçre bulunmaktadır.

OECD DIYYE ile çalışmada önerilen model arasındaki ilişkinin derecesi ve yönünü tespit etmek için Spearman rho sıra/rank korelasyon analizi sonuçlarına bakılmıştır. Bu sonuçlar değerlendirildiğinde 2017 yılı konut ve sivil katılım kriterleri hariç tüm kriterler için aynı yönlü pozitif ve güçlü ilişki bulunmuştur. Konut ve Sivil Katılım kriterleri arasında ise güçlü ve aynı yönlü pozitif ilişki bulunmuştur.

Eleştirel bir bakışla oluşturulan model ile OECD DİYE sonuçları arasında farklı sıralamalar gözlemlenmiştir. Aynı zamanda iki model arasında güçlü ve aynı yönlü pozitif ilişki tespit edilmiştir. Bu neticelerden yola çıkılarak kullanılan modelin OECD’nin daha iyi yaşam endeksi hesaplamasına seçenek oluşturabilecek bir model önerisi olmuştur.

Çalışma sonuçları III. Alan Yazın bölümünde verilen çalışmalar ile birlikte değerlendirildiğinde öncelikle karşılaştırmalar çok değişkenli istatistiksel analiz yöntemleri yerine matematiksel optimizasyona dayalı çok kriterli/amaçlı karar verme yöntemleri kullanılmıştır. Bu çerçevede çalışma yöntemsel olarak alan yazına katkı sağlamaktadır. İlgili ülkelere ait yayınlanmış son veri setlerinin çalışmada kullanılmış olması çalışmanın alan yazına sağladığı ikinci katkıdır. Ayrıca çalışmada önerilen yöntem ile elde edilen endeks ile OECD tarafından yapılan çalışmalar ile yayınlanan DİYE arasında yapılan sıralama korelasyonlarının istatistiksel anlamlılı̆̆ı ile önerilen sonuçların ilgili alanda yapılacak politika çalışmalarına farklı bir sonuç değerlendirmesi bakış açısı sağlaması da çalışmanın alan yazına kattığı üçüncü katkı olarak değerlendirilebilir.

Çalışmada OECD’nin oluşturduğu (DIYYE) endeksine yapılan temel eleştiri göstergelerin arasındaki önem düzeyleri ve bunların ağırlıklarının belirsiz olmasıdır. OECD web tabanında kriterlerin önem derecesinin kişiye göre düzenleme imkanını sadece ana göstergeleri için vermektedir. Herhangi bir ülke açısından değerlendirildiğinde ülkenin refahını düzeyi belirlenmek istenirse alt kriterlerin önem derecesini belirleme imkânı yoktur. Bu nedenle bir ülkenin kendisini OECD'nin diğer ülkeleri ile kıyaslaması ve bu kıyaslamada daha iyi yaşam endeksine göre sıralamasını (konumunu) görüp buna göre ülke içinde nasıl bir politika uygulanabileceği konusunda karar verebilmesi mümkün olamamaktadır. Bu eleştirilerden yola çıkılarak bu çalışmada önerilen model çerçevesinde OECD'nin endeks değerlendirme sonuçlarına alternatif farklı sonuçlar hesaplanmış ve aynı zamanda OECD'nin endeksi ile ülkelerin sıralaması ile önerilen model sonucu hesaplanan endeks ile yapılan ülke sıralaması arasında spearman sıra korelasyon ile güçlü ilişki bulunmuştur. Bu sonuçlar neticesinde çalışmada önerilen modelin OECD tarafından hesaplanan daha iyi yaşam endeksine karş1 seçenekli bir model olabileceği sonucu ortaya konmuştur.

Ülkemiz açısından değerlendirildiğinde Türkiye OECD’nin oluşturmuş olduğu DİYE ‘de yer alan temel ve alt boyutların göstergelerinin bir kısmında görece daha düşük değerlere sahiptir. Ancak çalışmada önerilen modelde de OECD göstergelerine benzer sonuçlar olmakla birlikte ülkemiz değerleri OECD'ye göre görece biraz daha iyileşmiştir. Alan yazında belirtilen çalışmalarda da vurgulandığı üzere refah kavramı kişiden kişiye değişmesinin yanında özellikle kültürel ve coğrafik yapılara göre de farklılık gösterebilmektedir. Bu nedenle çalışmada önerilen modelde uzmanlar tarafından Türkiye için refahı en iyi temsil edeceği düşünülen ağırlıklar hesaplanmıştır. Bu çerçevede önerilen model OECD'nin yapmış olduğu değerlendirmeye göre ülkemiz açısından daha iyi sonuçlara sahip çıkmaktadır. Bu nedenle modelde tercih edilen ağırlıklardan hareketle hem endeks sıralamasındaki yer hem de Türkiye için gerekli politik adımların atılması önemli olduğu düşüncesi ile bu çalışmanın Türkiye'de refahın iyileştirilmesine ve alan yazına katkı sağlayacağı düşünülmektedir. 


\section{Kaynakça}

Akar, S. (2014). Türkiye'de Daha İyi Yaşam Endeksi: OECD Ülkeleri ile Karşılaştırma. Journal of Life Economics. 1.1-12.

Ayyıldız, E. ve Demirci, E. (2018). Türkiye'de Yer Alan Şehirlerin Yaşam Kalitelerinin SWARA Entegreli TOPSIS Yöntemi ile Belirlenmesi. Pamukkale Üniversitesi Sosyal Bilimler Enstitüsü. 30.6887.

Başol, O. (2018). OECD Ülkelerinde Yaşam Tatmini Üzerine Bir Değerlendirme. İş, Güç Endüstri İlişkileri ve İnsan Kaynakları Dergisi. 20(3). 67 - 86.

Bergh, J. (2008). The GDP Paradox, Journal of Economic Psychology. 30.117-135.

Bergh, J. (2010). Relax About GDP Growth: Implications for Climate Change and Crisis Policies. Journal of Cleaner Production. 18(69). 540 - 543.

Çakır, E. ve Karabıyık, B. K. (2017). Bütünleşik SWARA- COPRAS Yöntemi Kullanarak Bulut Depolama Hizmet Sağlayıcılarının Değerlendirilmesi. Bilişim Teknolojileri Dergisi. 10(4). 417- 434.

Decancq, K. (2015). Measuring Multidimensional Inequality in the OECD Member Countries With a Distribution-Sensitive Better Life Index. Social Indicators Research. 386. 1-35.

Durand, M. ve Smith, C. (2013). The OECD Better Life Intiative: How's Life? and the Measurement of Well- Being. Paper Prepared for the IARIW Session at the 2013 World Statistics Conference Sponsored by the International Statistical Institute. Hong-Kong.

Engür, M. (2019). DELPHI ve Çok Kriterli Karar Verme Yöntemleri ile Öğrenci İsleri Otomasyon Seçimi. Yüksek Lisans Tezi. Kırıkkale Üniversitesi Sosyal Bilimler Enstitüsü. Kırıkkale.

Eren, H. (2016). PORMETHEE, MOORA ve COPRAS Yöntemleri ile Oran Analizi Sonuçlarının Değerlendirilmesi: Bir Uygulama. Yüksek Lisans Tezi. Süleyman Demirel Üniversitesi Sosyal Bilimler Enstitüsü. Isparta.

Gökkısa, A. C. ve Ayçin, E. (2019). OECD Ülkelerinin Lojistik Performanslarının SWARA Tabanlı EDAS Yöntemi ile Değerlendirilmesi. Çankırı Karatekin Üniversitesi İktisadi ve İdari Bilimler Fakültesi Dergisi. 9 (1). 301-325.

Hetschko, C., Reumont, L. V. ve Schöb, R. (2016). Embeddig Effects in the OECD Better Life Index: Evidence from an Experiment. Chair of International Public Economics. 20.1-29. [http://www.oecdbetterlifeindex.org/]. (Erişim: 20 Arallk 2020).

Ersöz, Yunus, Halis, İstanbul Üniversitesi Açık ve Uzaktan Eğitim Fakültesi Sosyal Hizmetler Ön Lisans Program1 Ders Notları. [http://auzefkitap.istanbul.edu.tr/ kitap/sosyalhizmetler_ao/ sosyalpolitika.pdf]. (Erişim: 12 Nisan 2021).

Karaduman, E. E. (2018). Hastane Personel Seçiminin Çok Kriterli Karar Verme Yöntemleriyle Karşılaştırmalı Analizi. Yüksek Lisans Tezi. Uşak Üniversitesi Sosyal Bilimler Enstitüsü. Uşak.

Kasparian, J., ve Rolland, A., (2012). OECD's Better Life Index: Can any Country be Well Ranked?. Research Article. Journal of Applied Statistics. 39(10). 1- 8.

Kernyi Adam (2011). The Better Life Index of the Organisation for Economic Co- Operationand Development. Public Finance Quarterly. 56(4).518 - 538.

Kulesza, M., ve Ucieklak-Jez, P., (2012). Poland and Selected Countriesin the Light of OECD's Better Life Index. Prace Naukowe Akademi im Jana Dáugosza Cz_Stochowie. Pragmatates Oikonomia. 6. 83-91.

Mehdi, T. (2018). Stochastic Dominance Approach to OECD’s Better Life Index. Social Indicators Research. 143. $917-954$.

Mizobuchi, Hideyuki (2013). Measuring world Better Life Frontier. Discussion Paper Series. No.1301. 1-23. 
Monika, G. T. (2018). The Weight of Weighting an Empiricial Study Based on the OECD Better Life Index, the Business and Management Rewiew. 9 (3). 443 - 449.

OECD. (2015). How's Life? 2015: Measuring Well-Being. OECD Publishing. Paris. 1- 257.

Podvezko, V. (2011). The Comparative Analysis of MCDA Methods SAW and COPRAS. Inzinerine Ekonomika-Engineering Economics. 22(2). 134- 136.

Sarıçalı, G., ve Kundakcı, N. (2016). AHP ve COPRAS Yöntemleri ile Otel Alternatiflerinin Değerlendirilmesi. International Review of Economics and Management. 4(1). 45- 66.

Stiglitz, J. E., Sen, A., ve Fitoussi, J. P., (2009). Report By the Commission on the Measurement of Economic Performance and Social Progress. [http://www.stiglitzksenk.fitoussi.fr/documents/rapport anglais.pdf]. (Erişim: 20 Aralık 2020). Paris.

Şahin, C. ve Öztel, A. (2017). Ülkelerin Yaşanabilirlik Düzeylerinin COPRAS Yöntemiyle Karşılaştırmalı Analizi: BRICS Ülkeleri ve Türkiye. Uluslararası Batı Karadeniz Sosyal ve Beşerî Bilimler Dergisi.1(1). 75- 84.

Şenaras, A. E. ve Çetin, I. (2016). OECD Ülkelerinde Refahın Daha İyi Yaşam Endeksi ile Analizi. PARADOKS Ekonomi. Sosyoloji ve Politika Dergisi. 11(2). 31- 51.

Uygurtürk, H. ve Soylu, N. (2016). Girişim Sermayesi Yatırım Ortaklıklarının Likidite ve Karlılık Performanslarının COPRAS Yöntemi ile Analizi. Hitit Üniversitesi Sosyal Bilimler Enstitüsü Dergisi. 9 (2). 637- 650 .

Yilmaz, O. (2017). International Welfare Comprasion Using GDP and Better Life Index Parameters. Journal of Economics. Finance and Accounting. 4(1). 1-14. 